\title{
Genetic evidence of multiple invasions and a small number of founders of Asian Palmyra palm (Borassus flabellifer) in Thailand
}

\author{
Kwanjai Pipatchartlearnwong ${ }^{1}$, Akarapong Swatdipong ${ }^{1,2}$, Supachai Vuttipongchaikij ${ }^{1,2,3^{*}}$ (D)
} and Somsak Apisitwanich 1,2,3,4*

\begin{abstract}
Background: Borassus flabellifer or Asian Palmyra palm is an important crop for local economies in the South and Southeast Asia for its fruit and palm sugar production. Archeological and historical evidence indicated the presence of this species in Southeast Asia dating back at least 1500 years. B. flabellifer is believed to be originated in Africa, spread to South Asia and introduced into Southeast Asia through commercial routes and dissemination of cultures, however, the nature of its invasion and settlement in Thailand is unclear.

Results: Here, we analyzed genetic data of 230 B. flabellifer accessions across Thailand using 17 EST-SSR and 12 gSSR polymorphic markers. Clustering analysis revealed that the population consisted of two genetic clusters (STRUCTURE $K=2$ ). Cluster I is found mainly in southern Thailand, while Cluster II is found mainly in the northeastern. Those found in the central are of an extensive mix between the two. These two clusters are in moderate differentiation $\left(F_{\mathrm{ST}}=0.066\right.$ and $\left.N_{M}=3.532\right)$ and have low genetic diversity $\left(H_{O}=0.371\right.$ and $0.416 ; A_{R}=2.99$ and 3.19 , for the cluster I and II respectively). The minimum numbers of founders for each genetic group varies from 3 to 4 individuals, based on simulation using different allele frequency assumptions. These numbers coincide with that $B$. flabellifer is dioecious, and a number of seeds had to be simultaneously introduced for obtaining both male and female founders.

Conclusions: From these data and geographical and historical evidence, we hypothesize that there were at least two different invasive events of B. flabellifer in Thailand. B. flabellifer was likely brought through the Straits of Malacca to be propagated in the southern Thailand as one of the invasive events before spreading to the central Thailand. The second event likely occurred in Khmer Empire, currently Cambodia, before spreading to the northeastern Thailand.
\end{abstract}

Keywords: Arecaceae, Expressed sequence tag- simple sequence repeat (EST-SSR), Genetic diversity, Genomic-simple sequence repeat (genomic SSR), Microsatellite marker, Minimum founder

\section{Background}

Biological invasions occurred both naturally and unnaturally, and the rate of invasions has been elevated since the rise of global trades [1-3]. Although invasive species theoretically pose problems for the well-being of natural communities and ecosystems [4-7], a large number of invasive plants have been deliberately introduced to new

\footnotetext{
* Correspondence: fsciscv@ku.ac.th; fscissa@ku.ac.th

'Department of Genetics, Faculty of Science, Kasetsart University, 50 Ngam

Wong Wan Road, Chatuchak, Bangkok 10900, Thailand

Full list of author information is available at the end of the article
}

areas due to various beneficial purposes including medicines, ornament, and food [8-10]. Borassus flabellifer (Asian Palmyra palm), as of African origin [11], is one of the invasive plants in Thailand and Southeast Asian countries. Although it is sometimes considered as indigenous to the Indian subcontinent, it is likely that B. flabellifer was spread out from Africa to South Asia before being introduced into Southeast Asia through commercial routes in the past $[12,13]$. In Southeast Asian countries, B. flabellifer is one of the oldest domesticated fruit crops estimating that it has been in Thailand since 1500 years 
ago. Almost all parts of the plant are used by the locals, and its fruit is widely consumed. Especially, sap from the inflorescence flower is the source for palm sugar production and alcoholic beverages. As a result, B. flabellifer was distributed and grown in many regions of Thailand in various soil and climatic conditions.

B. flabellifer, a dioecious monocotyledonous woody perennial tree in the family Arecaceae, is a massive palm with a single stem reaching $30 \mathrm{~m}$ in height and large fan-shaped leaves spanning $4-6 \mathrm{~m}$ in diameters [11]. $B$. flabellifer grows very slow, taking up to $12-20$ years to reach its maturity and produce its first inflorescence flowers. Sex determination based on plant morphology is not possible, and that based on molecular markers is currently unachievable. Previous genetic studies using various types of DNA markers showed that B. flabellifer populations have very low genetic diversity [14-17], and this was concerned as a potential threat to a sustainable use as the species is in decline through extensions of farmland, urbanization and its extremely long juvenile stage.

A standing question is whether the narrow genetic diversity of $B$. flabellifer should be a key consideration for its agricultural sustainability or it should be acknowledged that this had occurred through selection and domestication processes a long time ago. Here, we analyzed the genetic diversity and population structure of $B$. flabellifer across Thailand using microsatellite markers. The phylogeography was also observed, and the minimum numbers of founder individuals introduced into Thailand were estimated. Geographical and historical evidence was taken into account to form theoretical invasive events of $B$. flabellifer in Thailand and Southeast Asia.

\section{Methods}

\section{Plant materials, gDNA isolation and SSR amplification}

To obtain genetic data, B. flabellifer population was analyzed by 17 EST-SSR and 12 gSSR polymorphic markers (Table 1). These microsatellite markers, which were originally developed based on oil palm [17, 18], have been tested and evaluated for their transferability and polymorphism in B. flabellifer population. Young leaf samples were collected from 230 B. flabellifer accessions located throughout Thailand (31, 139 and 60 plants from southern, central and northeastern Thailand, respectively, see Additional file 1). An accession of oil palm was used as an outgroup. Total DNA was isolated from leaf samples using a modified CTAB extraction method [19]. PCR amplification was conducted as follows: an initial denaturation step of $5 \mathrm{~min}$ at $94^{\circ} \mathrm{C}$, followed by 35 cycles of three steps, $30 \mathrm{~s}$ at $94^{\circ} \mathrm{C}$, $1.30 \mathrm{~min}$ at the specific annealing temperature for each primer pair and $30 \mathrm{~s}$ at $72^{\circ} \mathrm{C}$, and a final extension step at $72^{\circ} \mathrm{C}$ for $8 \mathrm{~min}$. PCR products were resolved using $6 \%$ polyacrylamide gel electrophoresis and stained with silver nitrate (see Additional file 2 for representative polyacrylamide electrophoresis gels for the polymorphic loci). PCR fragments obtained for EST-SSRs and gSSRs were size-estimated based on the Low Molecular Weight DNA Ladder (Biolabs ${ }^{\bullet}$ Inc., New England).

\section{Genetic diversity and population structure analyses}

All loci were tested for linkage disequilibrium (LD) using PowerMarker version 3.25 [20]. The sequential Bonferroni correction [21] was performed according to the multiple tests. The Hardy-Weinberg equilibrium (HWE) was conducted using POPGENE version 1.31 [22]. PowerMarker V3.25 was used to determine polymorphism information content (PIC) based on Botstein et al. (1980) [23].

EST-SSR and gSSR data were used to infer the most likely number of population genetic clusters (K), based on a Bayesian approach implemented in STRUCTURE version 2.3.4 [24]. Each of individual B. flabellifer was initially grouped according to the sampling locations: provinces and geographical parts of Thailand. Assuming a population admixture model, 100,000 burn-ins and 100,000 Markov chain Monte Carlo (MCMC) replicates for $\mathrm{K}$ varied from 1 to 10 were performed. Twenty independent runs were performed for each $\mathrm{K}$. The best $\mathrm{K}$ was then inferred based on $\ln P(D)$ and delta $K$ [25]. A hierarchical analysis of molecular variance (AMOVA) was performed using Arlequin version 3.1 [26] to test for significance of grouping based on provinces and regional parts of Thailand and that of genetic clustering using STRUCTURE. The level of polymorphism was determined by using all 29 polymorphic loci. The observed $\left(H_{o}\right)$ and expected $\left(H_{E}\right)$ heterozygosity, the number of observed alleles and the number of effective alleles were calculated using POPGEN version 1.31. Allelic richness $\left(\mathrm{A}_{\mathrm{r}}\right)$ and pairwise $F_{\mathrm{ST}}$ among groups were calculated using FSTAT version 2.9.3.2 [27]. The number of migrants $\left(N_{\mathrm{M}}\right)$ was estimated using an equation according to Wright [28]: $N_{\mathrm{M}}=1\left(1 / F_{\mathrm{ST}^{-}}-1\right) / 4$.

\section{Minimum number of founders}

Although a number of methods for estimating a minimum number of founders based on genetic data are available, these are unsuitable for our dataset as they require genetic information from the source population and assume no admixture between introduced populations. Thus, to estimate the minimum number of founders, we used an approach developed by Rasner et al. [29], which requires empirically information from observed microsatellite alleles in each cluster of the studied species. Information based on best grouping identified using AMOVA result (i.e. maximum $F_{\mathrm{CT}}$ ) was used.

Custom-written scripts (see Additional file 3) based on program R 3.3.0 for simulating different numbers of founder genotypes was run for 10,000 replicates to find 
Table 1 Summary of the polymorphic microsatellite loci used in the B. flabellifer population

\begin{tabular}{|c|c|c|c|c|c|}
\hline Primer & Repeat motif & Primer sequence $\left(5^{\prime}-3^{\prime}\right)$ & $\operatorname{Tm}\left({ }^{\circ} \mathrm{C}\right)$ & Allele size (bp) & $\mathrm{PIC}$ \\
\hline \multirow[t]{2}{*}{ ESSR75 } & \multirow[t]{2}{*}{$(\mathrm{AAG})_{5}$} & \multirow{2}{*}{$\begin{array}{l}\text { F:AGATGGTTGGAGATTCATGGT } \\
\text { R:AACTTGAGGGTGCCATTACAAG }\end{array}$} & \multirow[t]{2}{*}{60} & $270-285$ & 0.38 \\
\hline & & & & $175-190$ & 0.44 \\
\hline \multirow[t]{2}{*}{ ESSR76 } & \multirow[t]{2}{*}{$(A G C)_{5}$} & \multirow{2}{*}{$\begin{array}{l}\text { F:CCATACCAGCAGAAGAGGATGT } \\
\text { R:CTGAAGGTCATAGGGGTCTCTG }\end{array}$} & \multirow[t]{2}{*}{60} & $350-365$ & 0.52 \\
\hline & & & & 190-205 & 0.56 \\
\hline ESSR82 & $(\mathrm{GCT})_{5}$ & $\begin{array}{l}\text { F:CCCTCGACACCCATAGTTATTT } \\
\text { R:CTCGATTTCTGGCCTCTCATAC }\end{array}$ & 60 & $200-215$ & 0.39 \\
\hline ESSR332 & $(\mathrm{AT})_{6}$ & $\begin{array}{l}\text { F:AGTTAATGTGTCAGGGCCAGTT } \\
\text { R:CTTGGTTCACTTGGGTGTGTC }\end{array}$ & 60 & $230-242$ & 0.42 \\
\hline \multirow[t]{2}{*}{ ESSR553 } & \multirow[t]{2}{*}{$(A)_{19}$} & \multirow{2}{*}{$\begin{array}{l}\text { F:ATAAATTGTGCGAGGGGAAAAC } \\
\text { R:AGATCCGCGACAGGTCTTAAC }\end{array}$} & \multirow[t]{2}{*}{60} & $220-239$ & 0.37 \\
\hline & & & & $125-144$ & 0.34 \\
\hline \multirow[t]{2}{*}{ ESSR566 } & \multirow[t]{2}{*}{$(A G)_{7}$} & \multirow{2}{*}{$\begin{array}{l}\text { F:GTGTCATCAAATTCGGTCCTTT } \\
\text { R:CGGTTCTTCTGCTGCTCTACTT }\end{array}$} & \multirow[t]{2}{*}{60} & $240-254$ & 0.44 \\
\hline & & & & $125-139$ & 0.56 \\
\hline ESSR609 & $(\mathrm{GA})_{7}$ & $\begin{array}{l}\text { F:AGGCGGTGATGAAGATGAAG } \\
\text { R:CTCCTCTCAAACAGAGTGGGAT }\end{array}$ & 59 & $150-164$ & 0.4 \\
\hline ESSR650 & $(A G)_{14}$ & $\begin{array}{l}\text { F:GCCTITCTGGTTAATGGACTG } \\
\text { R:GTTTGTCTATGGATGATTGTGAGG }\end{array}$ & 59 & $200-228$ & 0.32 \\
\hline ESSR652 & $(G A G)_{6}$ & $\begin{array}{l}\text { F:CATACCGTCACCACTCAGAAAC } \\
\text { R:GCCGTCATTCTACCAGTTGAG }\end{array}$ & 60 & $150-168$ & 0.33 \\
\hline \multirow[t]{2}{*}{ ESSR673 } & \multirow[t]{2}{*}{$(G G C)_{8}$} & \multirow{2}{*}{$\begin{array}{l}\text { F:TTCTGGCTACGAGCATAAGGA } \\
\text { R:TCAATAACCCTGGCTAAACACA }\end{array}$} & \multirow[t]{2}{*}{59} & $150-168$ & 0.23 \\
\hline & & & & $75-113$ & 0.36 \\
\hline \multirow[t]{2}{*}{ ESSR681 } & \multirow[t]{2}{*}{$(\mathrm{AAAT})_{5}$} & \multirow{2}{*}{$\begin{array}{l}\text { F:TCTGAATTGTCGGAGTGGC } \\
\text { R:CATCCTTGCGTAAACAAAAGAG }\end{array}$} & \multirow[t]{2}{*}{59} & $350-370$ & 0.49 \\
\hline & & & & $130-150$ & 0.56 \\
\hline mEgCIR2332 & $(G A)_{14}$ & $\begin{array}{l}\text { F:GAAGAAGAGCAAAAGAGAAG } \\
\text { R:GCTAGGTGAAAAATAAAGTT }\end{array}$ & 55 & $250-278$ & 0.38 \\
\hline \multirow[t]{2}{*}{ mEgCIR3295 } & \multirow{2}{*}{$\begin{array}{l}(\mathrm{GT})_{7} \\
(\mathrm{GA})_{23}\end{array}$} & \multirow{2}{*}{$\begin{array}{l}\text { F:TGCCTCCAGACAATCAC } \\
\text { R:GTAAGGCTTAACCAGATAAC }\end{array}$} & \multirow[t]{2}{*}{55} & $300-360$ & 0.62 \\
\hline & & & & $250-310$ & 0.16 \\
\hline mEgCIR3311 & $(G A)_{15}$ & $\begin{array}{l}\text { F:AATCCAAGTGGCCTACAG } \\
\text { R:CATGGCTTTGCTCAGTCA }\end{array}$ & 55 & $180-210$ & 0.31 \\
\hline \multirow[t]{2}{*}{ mEgCIR3413 } & \multirow[t]{2}{*}{$(G A)_{18}$} & \multirow{2}{*}{$\begin{array}{l}\text { F:AAAGCTATGGGGTGAAAGAT } \\
\text { R:TGGATAAGGGCGAGAAGAGA }\end{array}$} & \multirow[t]{2}{*}{55} & $350-386$ & 0.27 \\
\hline & & & & $250-286$ & 0.44 \\
\hline mEgCIR3477 & $(G A)_{22}$ & $\begin{array}{l}\text { F:CCTTCAAGCAAAGATACC } \\
\text { R:GGCACCAAACACAGTAA }\end{array}$ & 55 & $250-294$ & 0.15 \\
\hline mEgCIR3592 & $(G A)_{20}$ & $\begin{array}{l}\text { F:GAGCCAAAACAGACTTCAA } \\
\text { R:ACCGTATATGACCCCTCTC }\end{array}$ & 55 & $\begin{array}{l}230-270 \\
150-190\end{array}$ & $\begin{array}{l}0.46 \\
0.3\end{array}$ \\
\hline mEgCIR3755 & $(\mathrm{GA})_{15}$ & $\begin{array}{l}\text { F:GCTCACCAAAAAGTGTTAAGTC } \\
\text { R:AGTTTCAACGGCAGGTATAT }\end{array}$ & 55 & $\begin{array}{l}340-370 \\
140-170\end{array}$ & $\begin{array}{l}0.02 \\
0.1\end{array}$ \\
\hline mEgCIR3788 & $(G A)_{18}$ & $\begin{array}{l}\text { F:TTGTATGACCAAAGACAGC } \\
\text { R:AGCGCAACATCAGACTA }\end{array}$ & 55 & $180-216$ & 0.43 \\
\hline
\end{tabular}

the minimum number of founder individuals. This was performed in two criteria: simulating using the complete set of genotypes contain all the microsatellite alleles in the dataset and simulating using a data set excluding the low frequency alleles $(<0.02)$. In accounting for the effects of sampling bias and genetic drift in small populations, the $\mathrm{R}$ scripts were run in three following setting: (1) randomly resampling alleles-independently for each locus-without replacement from the data set, (2) resampling from allele frequency distribution at each locus and (3) resampling from allele frequency distributions by assuming equal allele frequencies at each locus.

\section{Results}

EST-SSR and gSSR analyses of a B. flabellifer population in Thailand

In total, 17 EST-SSR and 12 gSSR polymorphic loci in 230 B. flabellifer individuals were analyzed. Sequential Bonferroni correction was applied due to the multiple tests, and the LD test revealed that these 29 loci were not physically linked (Table 1 ). Thus, all loci were used 
for downstream genetic analysis. The PIC value across the polymorphic loci was 0.37 . The PIC values of 17 EST-SSRs were $0.23-0.56$ (average of 0.42 ), and those of 12 gSSRs were $0.02-0.62$ (average of 0.32 ).

\section{STRUCTURE clustering of $B$. flabellifer}

The genotypic data of the B. flabellifer based on the 29 loci were subjected to clustering analysis using STRUCTURE program. Initially, the best $\mathrm{K}$ from the genotypic data following Pritchard et al. [24] was unable to be obtained, because the $\ln P(\mathrm{D})$ increased continually as the $\mathrm{K}$ increased (data not shown). The delta $\mathrm{K}$ statistics based on Evanno et al. [25] was then applied and indicated the best $\mathrm{K}=2$ for a STRUCTURE clustering analysis using sampling locations based on either provinces or geographical areas (Fig. 1).

Among the four alternative grouping types, the hierarchical analysis of molecular variance (AMOVA) showed that grouping based on STRUCTURE assisted by the three sampling regions was the most suitable for these samples as indicated by the highest $F_{\mathrm{CT}}$ (max $F_{\mathrm{CT}}=0.06266$; Table 2). It indicated that the genetic variation of the $B$. flabellifer in Thailand was highest within the populations (86.13\%) followed by among populations (7.6\%) and smallest among clusters (6.27\%). Therefore, the grouping as two clusters was used for subsequent analyses. By mapping the clusters and sample sizes, it revealed that $B$. flabellifer individuals from cluster I dominate southern Thailand, while those from cluster II dominate the northeastern (Fig. 2). Individuals from the two clusters were found equally in the central region and mixed in a number of provinces. The ratio of the two clusters found within the same sampling sites was found varied greatly among provinces.

\section{Genetic diversity of the B. flabellifer based on STRUCTURE clustering}

The microsatellite data of the two clusters based on STRUCTURE clustering were separately analyzed. It showed that 120 and 110 individuals of the cluster I and II, respectively, had low numbers of observed alleles, effective alleles, observed heterozygosity and heterozygosity (Table 3). Estimated allelic richness based on a minimal sample size of 96 diploid individuals were 3.00 and 3.19 for the cluster I and II, respectively. This result indicated that both cluster I and II have very low genetic diversity. Each cluster was found to be highly significantly deviated from HWE $(p<0.0001)$. This is most likely because the $B$. flabellifer is dioecious, allowing gene flow between the two clusters within the same sampling sites. The $F_{\mathrm{ST}}$ and $N_{\mathrm{M}}$ values between both clusters were 0.066 and 3.532, respectively, indicating that these clusters are in moderate differentiation with a moderate gene flow.

\section{The minimum number of $B$. flabellifer founders in Thailand} As indicated by historical evidence and supported by the low genetic diversity, B. flabellifer was introduced into Thailand, and, thus, could be originated from a considerably small number of founders. The number

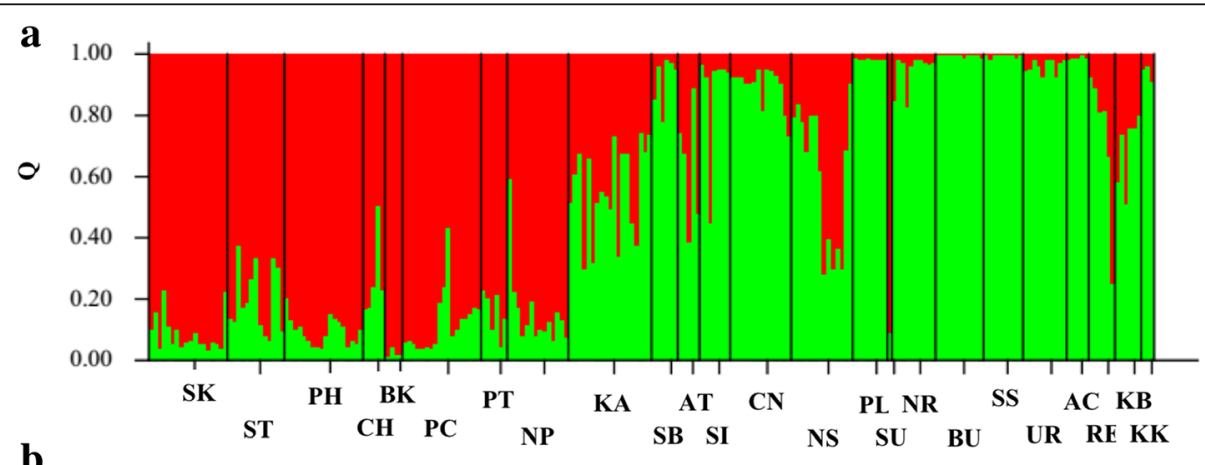

b

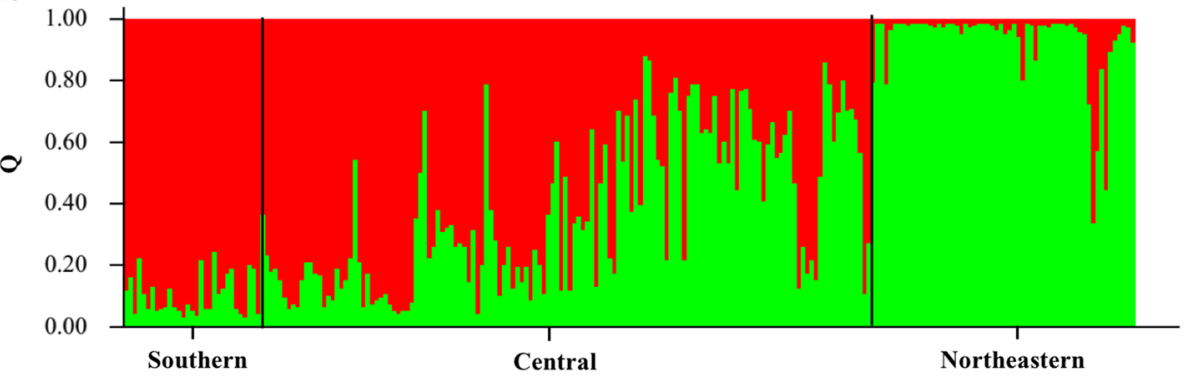

Fig. 1 Genetic clustering of 230 B. flabellifer individuals based on STRUCTURE analyses using information of sampling sites by 24 provinces (a) and three regions $(\mathbf{b})$. The best $\mathrm{K}(\mathrm{K}=2)$ is indicated for both clusters 
Table 2 Hierarchical analysis of molecular variance (AMOVA) of four grouping types based on sampling locations or STRUCTURE clustering assisted by sampling locations

\begin{tabular}{|c|c|c|c|c|}
\hline Grouping & Source of variation & Total variation & Percentage & FCT \\
\hline \multirow[t]{4}{*}{24 groups based on provinces } & Among clusters & 0.20839 & 4.13 & \multirow[t]{4}{*}{$0.04131(p<0.0001)$} \\
\hline & Among populations within clusters & 0.40812 & 8.09 & \\
\hline & Within populations & 4.42753 & 87.78 & \\
\hline & Total & 5.04405 & & \\
\hline \multirow[t]{4}{*}{3 groups based on geographical areas } & Among clusters & 0.21782 & 3.42 & \multirow[t]{4}{*}{$0.03416(p<0.0001)$} \\
\hline & Among populations within clusters & 0.62788 & 9.85 & \\
\hline & Within populations & 5.53157 & 86.74 & \\
\hline & Total & 6.37727 & & \\
\hline \multirow{4}{*}{$\begin{array}{l}2 \text { clusters based on STRUCTURE assisted } \\
\text { by sampling provinces }\end{array}$} & Among clusters & 0.26121 & 5.19 & \multirow[t]{4}{*}{$0.05192(p<0.0001)$} \\
\hline & Among populations within clusters & 0.36636 & 7.28 & \\
\hline & Within populations & 4.40375 & 87.53 & \\
\hline & Total & 5.03132 & & \\
\hline \multirow{4}{*}{$\begin{array}{l}2 \text { clusters based on STRUCTURE assisted } \\
\text { by geographical areas }\end{array}$} & Among clusters & 0.31992 & 6.27 & \multirow[t]{4}{*}{$0.06266(p<0.0001)$} \\
\hline & Among populations within clusters & 0.38812 & 7.6 & \\
\hline & Within populations & 4.39782 & 86.13 & \\
\hline & Total & 5.10586 & & \\
\hline
\end{tabular}

of B. flabellifer founders was estimated using the microsatellite data. As expected, the total number of alleles included in the analysis affected the estimated minimum number of founders (Table 4). The minimum numbers were estimated based on the genotypes, which were simulated by resampling from the allele frequency distributions. When resampling all empirical alleles in the dataset, an inclusion of all alleles potentially resulted in an overestimation of the number of the original founders of the two clusters (34 and 25 for cluster I and II, respectively). After removing the low frequency alleles, 13 and 9 founders were estimated for the cluster I and II, respectively. Depending on the reference dataset used, estimated numbers for the cluster I varied between 13 and 34 founders, and the cluster II varied between 9 and 25 founders. Finally, the simulation assuming equal allele frequencies at all loci consistently gave the lowest number of founders; four founders for both two clusters when using the dataset with all alleles and three founders for both clusters when using the dataset without low frequency alleles.

\section{Discussion}

Currently, there are two hypotheses regarding the origin of B. flabellifer. First, although there is so far no report on the presence of this species in Africa, it is thought to be originated in this continent [11] and then spread into India at least 2500 year ago, based on a report by the Greek historian Megasthenes, ambassador to the court of Chandragupta $[12,13]$. An alternative hypothesis is that B. flabellifer is native to South Asia, Southeast Asia, New Guinea and Tropical Africa (Morton 1988). However, the recent evidence favors the first hypothesis as five of six Borassus species are found in Africa, and, specifically, B. aethiopum and B. akeassii have similar morphology to that of $B$. flabellifer [30-32]. It can be postulated that B. flabellifer was spread to India and its subcontinent and later to Southeast Asia because of its values in palm sugar production and alcohol products.

B. flabellifer was brought to Southeast Asia most likely through the commercial routes and dissemination of cultures a long time ago. Based on our results, we hypothesize that the $B$. flabellifer was introduced into the areas, which are currently parts of Thailand, from two directions. Based on geographical reasons and historical commercial routes, one could be initially introduced into the southern part of Thailand, possibly from the Straits of Malacca as the world important shipping route since the past [33]. Another was likely introduced into the northeastern, possibly through Vietnam, Cambodia or Laos. These neighboring countries had long been interconnected for transferring and sharing cultures and goods since the historical time. Furthermore, our result showing a wide separation between the two clusters reflects the fact that there are mountain ranges that obstructed the movement between two clusters in the northeastern and the rest of Thailand. Nevertheless, the mix between the two clusters might have occurred gradually at the later time. 


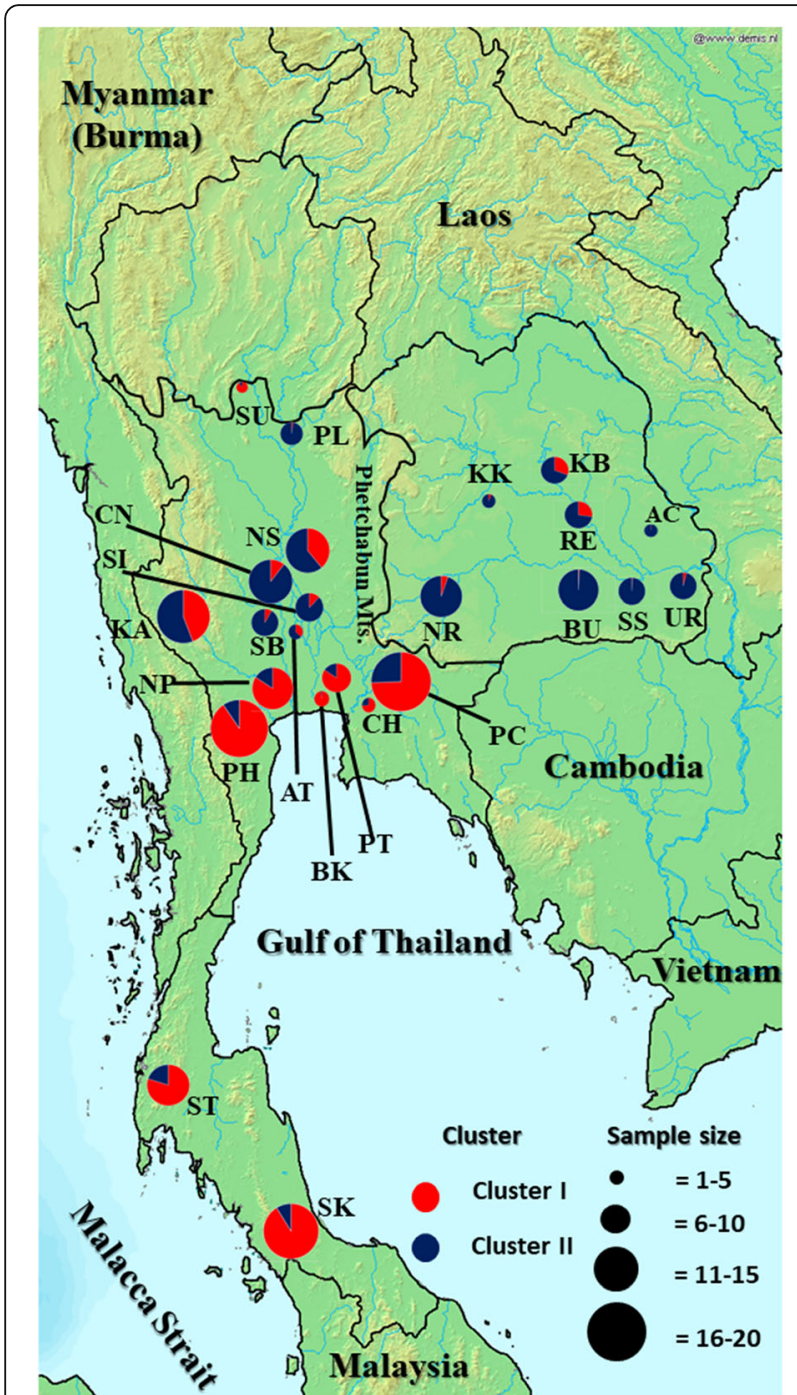

Fig. 2 Geographical distribution of the STRUCTURE clusters $(K=2) B$. flabellifer in Thailand. The map depicted here was taken from Wikimedia Commons. Colors in pie charts represented the different clusters. The sizes of pie chart represented sample sizes. For abbreviation of provinces see Additional file 1
Table 3 Genetic diversity across 29 polymorphic microsatellite loci on the two STRUCTURE clusters of the B. flabellifer population

\begin{tabular}{lllllll}
\hline Cluster & $\mathrm{n}$ & $\mathrm{N}_{\mathrm{A}}$ & $\mathrm{N}_{\mathrm{E}}$ & $\mathrm{H}_{\circ}$ & $\mathrm{H}_{\mathrm{e}}$ & $\mathrm{A}_{R}$ \\
\hline 1 & 120 & 3.0345 & 1.7494 & 0.3705 & 0.392 & 2.998793 \\
2 & 110 & 3.2069 & 1.984 & 0.4163 & 0.4431 & 3.191897 \\
Mean & 115 & 3.1207 & 1.8667 & 0.3934 & 0.4176 & 3.0953
\end{tabular}

Sample number $(n)$, the number of observed alleles (NA), the number of effective alleles (NE), the observed $(\mathrm{Ho})$ and expected $(\mathrm{HE})$ heterozygosity and allelic richness (AR) base on a minimal sample size of 96 diploid individuals are presented
Table 4 Estimated minimum numbers of founders required to introduce all empirically observed microsatellite alleles into each STRUCTURE cluster of the B. flabellifer population

\begin{tabular}{llll}
\hline Cluster & Resampling of alleles & Allele frequency & Equal frequency \\
\hline (a) & & 39 & 4 \\
Cluster I & 34 & 27 & 4 \\
Cluster II & 25 & & \\
(b) & & 10 & 3 \\
Cluster I & 13 & 9 & 3 \\
Cluster II & 9 & 9
\end{tabular}

The simulations were performed using (a) the complete set of genotypes assigned to each cluster or (b) excluding low frequency alleles $(<0.02)$. Estimates were obtained using three different approaches: resampling of alleles (without replacement), empirical allele frequency, and equal allele frequency

Historical and archeological evidence indicated the presence of B. flabellifer in Thailand since at least 1500 years ago. This evidence includes the discovery of a stone sealing in the Dvaravati period (central Thailand 1500 years ago) showing a man climbing a palm tree [34] and an identification of B. flabellifer pollen in archeological specimens aged $\sim 1500$ years in Songkhla province, southern Thailand [35]. We speculate that the southern Thailand was the introduction route of the cluster I via the Straits of Malacca, rather than Myanmar. This is because areas of the two countries are separated by high and long mountain ranges.

Our finding of the second settlement in the northeastern Thailand was firstly unexpected. Nonetheless, there is a number of evidence supporting this finding, including archeological studies in Angkor Borei in southern Cambodia that found pollen and tissues of B. flabellifer dating back approximately 1400-1500 years [36, 37]. Although there are also ancient scripts describing the presence of $B$. flabellifer in Laos in the past 1500 years $[38,39]$, we envisage that $B$. flabellifer in the northeastern Thailand was likely introduced from the areas, where it is now Cambodia, rather than Laos or Vietnam. This is because our result showed that the cluster II is concentrated at the lower part of the northeastern Thailand next to the Cambodia border, which has no major natural barriers. Noting that, in 7th centuries, this area in the northeastern Thailand belonged to the Khmer Empire. Furthermore, because there are long mountain ranges that separate between Vietnam and Laos, it is unlikely that B. flabellifer was introduced into Thailand through Vietnam, Laos and Mekong river. More samples from the neighboring countries are required to obtain a clearer picture of the B. flabellifer introduction route in Southeast Asia.

Since B. flabellifer requires $12-20$ years to reach its flowering stage and considering the 1500 years of settlement, this means that the species has been reproducing in Thailand for at least 125 generations. Thus, it is not surprising that our observed allele diversity was very low 
when considering the number of generation and genetic variation indexes. Likewise, no clear phenotypic variations among the population have been identified. Furthermore, the genetic study of this species in India, as thought to be the origin of B. flabellifer in Southeast Asia, using RAPD markers also showed low genetic diversity [15, 16, 40-43].

Simulation for the minimum number of founders estimated that 3-4 individuals settled in the southern and northeastern Thailand represent the founders of the cluster I and II, respectively. B. flabellifer is dioecious, and both male and female seeds are required for successful propagation and reproduction. Because there was no mean for sex determination and it takes at least 12 years to verify the sex of individual plants, a number of seeds had to be simultaneously introduced. This number could have been as low as 3-4 seeds to cover a potential outcome for both sexes. This might suggest that, in such case, the introduction was likely occurred through a human activity for exploiting B. flabellifer. In addition, this may suggest that, at that period, the human might have learned that $B$. flabellifer requires both male and female trees for fruit production and breeding.

B. flabellifer is an invasive plant successfully spreading throughout Thailand and Southeast Asia countries in spite of low genetic diversity. The low genetic diversity of invasive species is commonly referred as the genetic paradox of invasive organisms [44]. The genetic paradox of the B. flabellifer may be explained as this plant is useful for human uses, consumption and, perhaps, has tolerant capacities to insects, diseases and environmental challenges at the invading areas. Hence, the successful invasion of $B$. flabellifer was assisted through human activities.

\section{Conclusions}

In this work, we analyzed the genetic data of $230 \mathrm{~B}$. flabellifer individuals collected throughout Thailand using 17 EST-SSR and 12 gSSR polymorphic markers. The population was divided into two clusters according to STRUCTURE analysis (delta $K$, best $K=2$ ) based on three sampling regions, supporting by AMOVA (maximum $F_{\mathrm{CT}}=0.06266$ ). The cluster I was found predominately in the central and southern Thailand, while the cluster II was found mostly in the northeastern. The minimum number of founders was estimated using the microsatellite data, and it was likely that up to four individuals of each cluster were introduced into two different regions in Thailand. This study proposes the origin of B. flabellifer that was introduced into two different locations in the past, and this may also explain the low genetic diversity of the population in Thailand.

\section{Additional files}

Additional file 1: Locations of the B. flabellifer samples in Thailand (DOCX $14 \mathrm{~kb}$ )

Additional file 2: Representative polyacrylamide electrophoresis gels for the polymorphic loci (DOCX 9268 kb)

Additional file 3: An R script for simulating different numbers of founder genotypes (DOCX $24 \mathrm{~kb}$ )

\section{Abbreviations}

AMOVA: Analysis of molecular variance; CTAB: Cetyltrimethylammonium bromide; EST-SSR: Expressed sequence tag- simple sequence repeat; gSSR: Genomic simple sequence repeats; HWE: Hardy-Weinberg equilibrium; LD: Linkage disequilibrium; PIC: Polymorphism Information Content; RAPD: Random amplified polymorphic DNA

\section{Acknowledgements}

We thank Dr. Anongpat Suttangkakul for discussion and proofreading.

\section{Funding}

This work was supported by Kasetsart University Research and Development Institute (KURDI), Faculty of Science Research Fund (ScRF). Kwanjai Pipatchartlearnwong is supported by a PhD studentship from Kasetsart University and Faculty of Science.

Availability of data and materials

The datasets used and analyzed during the current study are available from the corresponding author on reasonable request.

Authors' contributions

SA and SV conceived and designed the experiments. KP and AS performed experiments. KP, SV and AS analyzed the data and wrote the manuscript. KP prepared the Figures and Tables. SA, SV and AS corrected and proofread the manuscript. All authors read and approved the final manuscript.

Ethics approval and consent to participate

All samples were collected from plants grown in private properties in Thailand, and we confirm that we had permissions to collect the plant materials.

Consent for publication

Not applicable.

Competing interests

The authors declare that they have no competing interests.

\section{Publisher's Note}

Springer Nature remains neutral with regard to jurisdictional claims in published maps and institutional affiliations.

\section{Author details}

${ }^{1}$ Department of Genetics, Faculty of Science, Kasetsart University, 50 Ngam Wong Wan Road, Chatuchak, Bangkok 10900, Thailand. ${ }^{2}$ Center of Advanced studies for Tropical Natural Resources, Kasetsart University, 50 Ngam Wong Wan Road, Chatuchak, Bangkok 10900, Thailand. ${ }^{3}$ Special Research Unit in Microalgal Molecular Genetics and Functional Genomics (MMGFG),

Department of Genetics, Faculty of Science, Kasetsart University, 50 Ngam Wong Wan Road, Chatuchak, Bangkok 10900, Thailand. ${ }^{4}$ School of Science, Mae Fah Luang University, Chiang-Rai 57100, Thailand.

Received: 24 May 2017 Accepted: 1 October 2017

Published online: 12 October 2017

\section{References}

1. Carlton JT. Introduced species in U.S. coastal waters: pew oceans commissions report. Washington, DC: Pew Oceans Commissions; 2001.

2. Colautti RI, Maclsaac HJA. Neutral terminology to define 'invasive' species. Divers Distrib. 2004;10:134-41. 
3. Heutte T, Bella E, Snyder J, Shephard M. Invasive plants and exotic weeds of Southeast Alaska. Alaska: Anchorage; 2003.

4. Pimentel D, Lach L, Zuniga R, Morrison D. Environmental and economic costs of nonindigenous species in the United States. Bioscience. 2000;50:53-65.

5. Schlaepfer MA, Sherman PW, Blossey B, Runge MC. Introduced species as evolutionary traps. Ecol Lett. 2005;8:241-6.

6. Pauchard A, Shea K. Integrating the study of non-native plant invasions across spatial scales. Biol Invasions. 2006;8:399-413.

7. Gilchrist GW, Lee CE. All stressed out and nowhere to go: does evolvability limit adaptation in invasive species? Genetica. 2007;129:127-32.

8. Lowe S, Browne M, Boudjelas S, De Poorter M. 100 of the world's worst invasive alien species: a selection from the global invasive species database. In: Species Survival Commission. Auckland: World Conservation Union; 2001.

9. Blömer U, Ganser A, Scherr M. Invasive drug delivery. Adv Exp Med Biol. 2002:513:431-51.

10. Téllez TR, López EMDR, Granado GL, Pérez EA, López RM, Guzmán JMS. The water hyacinth, Eichhornia Crassipes: an invasive plant in the Guadiana River basin (Spain). Aquat Invasions. 2008;3(1):42-53.

11. Kovoor A. The Palmyrah palm: potential and perspectives (FAO plant production and protection paper). Rome: FAO; 1983.

12. Ferguson W. Description of the Palmyrah palm of Ceylon. 1888

13. Fox JJ. Harvest of the palm: ecological change in eastern Indonesia. Cambridge (MA): Harvard University Press; 1977.

14. Vinayagam P, Dhandapani J, Raman P, Alagarsamy RK, Muthusamy P, Balaraman SS. Molecular characterization for genetic diversity of Palmyrah (Borassus flabellifer) accessions using inter simple sequence repeat (ISSR) markers. Asian Australas J plant Sci. Biotechnol. 2009;3(1):11-5.

15. Ponnuswami V. Genetic diversity in Palmyrah genotypes using morphological and molecular markers. Electron J. Plant Breed. 2010;1(4):556-67.

16. Raju DC, Reji JV. Genetic diversity analysis in Palmyrah palms using RAPD markers. Int. J Pharm Bio Sci. 2015:6:244-50.

17. Billotte N, Marseillac N, Risterucci AM, Adon B, Brottier P, Baurens FC, Singh R, Herrán A, Asmady H, Billot C, Amblard P, Durand-Gasselin T, Courtois B, Asmono D, Cheah SC, Rohde W, Ritter E, Charrier A. Microsatellite-based high density linkage map in oil palm (Elaeis guineensis Jacq.). Theor Appl Genet. 2005;110(4):754-65.

18. Ukoskit K, Chanroj V, Bhusudsawang G, Pipatchartlearnwong K, Tangphatsornruang S, Tragoonrung S. Oil palm (Elaeis guineensis Jacq.) linkage map, and quantitative trait locus analysis for sex ratio and related traits. Mol Breed. 2014;33(2):415-24

19. Gawel NLA, Jarnet RL. Modified CTAB DNA extraction procedure of Musa and Ipomoea. Plant Mol Bio Prr. 1991;9:262-6.

20. Liu K, Muse SV. PowerMarker: an integrated analysis environment for genetic marker analysis. Bioinformatics. 2005;21:2128-9.

21. Holm SA. Simple sequentially rejective multiple test procedure. Scand J Stat. 1979:6:65-70.

22. Yeh FC, Yang R, Boyle T: POPGENE version 1.32. Ag/for molecular biology and biotechnology Centre, University of Alberta and Center for International Forestry Research. 1997.

23. Botstein D, White RL, Skolnick M, Davis RW. Construction of a genetic linkage map in man using restriction fragment length polymorphisms. Am J Hum Genet. 1980;32:314-31.

24. Pritchard JK, Stephens M, Donnelly P. Inference of population structure using multilocus genotype data. Genetics. 2000;155:945-59.

25. Evanno G, Regnaut S, Goudet J. Detecting the number of clusters of individuals using the software STRUCTURE: a simulation study. Mol Ecol. 2005;14:2611-20.

26. Excoffier L, Laval G, Schneider S. Arlequin (version 3.0): an integrated software package for population genetics data analysis. Evol Bioinformatics Online. 2005;1:47-50

27. Goudet J: FSTAT, a program to estimate and test gene diversities and fixation indices. 2001, [http://www2.unil.ch/popgen/softwares/fstat.htm].

28. Wright S. Evolution and the genetics of populations. Vol. 2. Theory of gene frequencies. Chicago, USA: University of Chicago Press; 1969.

29. Rasner CA, Yeh P, Eggert LS, Hunt KE, Woodruff DS, Price TD. Genetic and morphological evolution following a founder event in the dark-eyed junco, Junco Hyemalis Thurberi. Mol Ecol. 2004;13:671-81.

30. Bayton RP, Ouédraogo A, Guinko S. The genus Borassus (Arecaceae) in West Africa with a description of a new species from Burkina Faso. J Linnean Soc. 2006;150:419-27.
31. Bayton RP, Ouédraogo A. Discovering Africa's newest palm. Palms 2009;53:37-45.

32. Ouoba LI, Kando C, Parkouda C, Sawadogo-Lingani H, Diawara B, Sutherland JP. The microbiology of Bandji, palm wine of Borassus akeassii from Burkina Faso: identification and genotypic diversity of yeasts, lactic acid and acetic acid bacteria. J Appl Microbiol. 2012;113(6):1428-41.

33. Freeman DB. Straits of Malacca: gateway or gauntlet? Canada: McGillQueen's Press-MQUP; 2003

34. Stargardt J, Satingpra I. The environmental and Economicentury archaeology of South Thailand. BAR international series 158. Oxford: Archaeopress; 1983.

35. Ghosh S, Ghosh L. Seals, amulets and coinages of Dvaravati cultural sites: understanding their social environment and religious network. Bull IndoPacific Prehistory Association. 2012;31:25-9.

36. Bishop P, Penny D, Stark M, Scott M. A 3.5ka record of paleoenvironments and human occupation at Angkor Borei, Mekong delta, southern Cambodia. Geoarchaeology. 2003;18(3):359-93.

37. Penny D, Pottier C, Fletcher R, Barbetti M, Fink D, Hua Q. Vegetation and land-use at Angkor, Cambodia: a dated pollen sequence from the Bakong temple moat. Antiquity. 2006;80(309):599-614.

38. Gyllenhaal C, Kadushin MR, Southavong B, Sydara K, Bouamanivong S, Xaiveu M, Xuan LT, Hiep NT, Hung NV, Loc KP, Dac LX, Bich TQ, Cuong MN, Ly HM, Zhang HJ, Franzblau SG, Xie H, Riley MC, Elkington BG, Nguyen HT, Waller DP, Ma CY, Tamez P, Tan GT, Pezzuto JM, Soejarto DD. Ethnobotanical approach versus random approach in the search for new bioactive compounds: support of a hypothesis. Pharm Biol. 2012;50(1):30-41.

39. Elkington BG, Sydara K, Hartmann JF, Southavong B, Soejarto DD. Folk epidemiology recorded in palm leaf manuscripts of Laos. J Lao Stud. 2013;3(1):1-14.

40. Ponnuswami V, Jagadeesan R, Ramesg Kumar A, Prabhu M, Makesh S. Genetic relationship and diversity in Palmyrah accessions based on RAPD marker. Am.-Eurasian. J Sustain Agric. 2008;2:165-71.

41. Ponnuswami V, Chitra S. Variability and association among fruit traits in Palmyrah (Borassus flabellifer L.). Electron J. Plant Breed. 2011;2(4):589-91.

42. George J, Karun A. Marker assisted detection of seed sex ratio in Palmyrah palm (Borassus Flabellifer L.). Curr Sci. 2011;100(6):922-5.

43. George J, Venkataramana K, Nainar P, Rajesh M, Karun A. Evaluation of molecular diversity of ex situ conserved germplasm of Palmyrah (Borassus Flabellifer L.) accessions using RAPD markers. J Plant Crops. 2016;44(2):96-102.

44. Frankham R. Resolving the genetic paradox in invasive species. Heredity. 2005;94(4):385-385

\section{Submit your next manuscript to BioMed Central and we will help you at every step:}

- We accept pre-submission inquiries

- Our selector tool helps you to find the most relevant journal

- We provide round the clock customer support

- Convenient online submission

- Thorough peer review

- Inclusion in PubMed and all major indexing services

- Maximum visibility for your research

Submit your manuscript at www.biomedcentral.com/submit 